\title{
Bacteriophage X-2: a Filamentous Phage Lysing IncX-Plasmid-harbouring Bacterial Strains
}

\author{
By J. N. COETZEE, ${ }^{1 *} \dagger$ D. E. BRADLEY, ${ }^{2}$ LAUREEN DU TOIT ${ }^{1}$ \\ AND THE LATE R. W. HEDGES ${ }^{3}$ \\ ${ }^{1}$ Department of Microbiology, University of Pretoria and Bacterial Genetics Research Unit of the \\ South African Medical Research Council, PO Box 2034, Pretoria 0001, South Africa \\ ${ }^{2}$ Faculty of Medicine, Memorial University of Newfoundland, St John's, Newfoundland, \\ Canada AlB 3 V6 \\ ${ }^{3}$ Plant Genetic Systems, Rijksuniversiteit Gent, Josef Plateau Straat 22, B-9000, Gent, Belgium
}

(Received 17 March 1988; revised 23 May 1988)

Phage X-2, a filamentous rod about $950 \mathrm{~nm}$ in length, was isolated from sewage as plating on strains of Escherichia coli, Salmonella typhimurium or Serratia marcescens carrying either the IncX plasmid R6K, or the unique plasmid R775. Phage X-2 differs morphologically from a previously described very broad host range filamentous phage $X$ which also lyses plasmid R6Kcarrying strains and the phages differ in their resistance to inactivation by diethyl ether. Phage $X-2$ is serologically unrelated to phage $X$ and the $X$-like phages $I_{K e}$ and $I_{2}-2$. The adsorption site of the phage on the plasmid-bearing strains could not be determined but evidence implicating conjugative pili is presented.

\section{INTRODUCTION}

The IncX group of plasmids (Hedges et al., 1973) was established with plasmid R6K (Kontamichalou et al., 1970) and the apparently identical pair of plasmids, R485 and R487 (Hedges et al., 1973), as members. Plasmid R6K, the prototype, has a mass of $26 \mathrm{MDa}$ (Kontamichalou et al., 1970) and codes for thick flexible pili belonging to morphological group 2 of Bradley (1980). The group now comprises eight members and conjugative pilus synthesis is repressed in all members apart from plasmid R6K, which forms these pili constitutively (Bradley et al., 1981a).

The filamentous phage $\mathrm{X}$ was isolated from sewage as plating on an Escherichia coli host carrying plasmid R6K (Bradley et al., 1981a). Apart from its specificity for IncX-harbouring bacteria, it differed from other filamentous phages in other respects: phage $\mathrm{X}$ has a frankly curly appearance (Bradley et al., 1981 a; Bradley et al., 1983) compared to filamentous phages like f1 (Caro \& Schnös, 1966), IKe (Khatoon et al., 1972; Bradley et al., 1983), PR6FS (Bradley, 1983), C-2 (Bradley et al., 1982a), SF (Coetzee et al., 1986) and tf-1 (Coetzee et al., 1987). Secondly the phage had a very broad host range in that it plated on bacterial strains harbouring plasmids of Inc groups $I_{2}, M, N, P-1, U$ and $W$. This host range partially overlaps that of phages IKe and $\mathrm{I}_{2}-2$ (Coetzee et al., 1982) and these phages are here named X-like for that reason (see Bradley et al., 1983).

During a search for an RNA-containing phage specific for IncX plasmid-containing bacteria, another filamentous phage adsorbing to IncX plasmid-bearing bacterial strains was isolated. Here properties of this phage are described.

\section{METHODS}

Bacteria. E. coli strains used were JE2571 and the corresponding nalidixic-acid- and rifampicin-resistant (rif ${ }^{\mathrm{R}}$ ) mutants JE2571-1 and -2, respectively (Bradley, 1980, 1985). The Salmonella typhimurium strain was M827-2, a

† Present address: 61 Charles Street, Baileys Muckleneuk, 0181 Pretoria, South Africa.

0001-4781 (C) 1988 SGM 
spontaneous rif ${ }^{\mathrm{R}}$ mutant of the LT2 strain M827 (Spratt et al., 1973). Sr41-2 is a spontaneous rif ${ }^{\mathrm{R}}$ mutant (J. N. Coetzee, unpublished) of Serratia marcescens strain 41 (Matsumoto et al., 1973). Klebsiella pneumoniae G162 and $K$. oxytoca G147 were provided by Dr I. Simpson (Glaxo, Greenford, Middlesex, UK). Members of the tribe Proteae used were Proteus mirabilis PM5006 (Coetzee et al., 1979), P. rettgeri NCTC8893 (Coetzee, 1983), P. morganii 2815-1 (Coetzee et al., 1985b) and Providencia alcalifaciens P29-2 (Coetzee et al., 1985a).

Plasmids and bacteriophages. Plasmids were from the collection of N. Datta (Datta, 1979). Some of the plasmids (Bradley et al., 1981 a) are listed in Table 2. Strain JE2571, carrying the IncF1 plasmid R386 (Dennison, 1972) was the indicator for phage fd (see below). Other plasmids belonging to Inc groups C (Sirgel et al., 1981), D (Coetzee et al., 1985a), HI and HII (Coetzee et al., 1985 b), J (Bradley et al., 1982a), S (Coetzee et al., 1986) and T (Bradley et al., $1981 \mathrm{~b}$; Coetzee et al., 1987) were also used in phage host-range experiments. Constitutive production of conjugative pili by the above plasmids was assessed by the ability of corresponding plasmid-specific phages, described in the same references, to form plaques on lawns of the plasmid-bearing organisms. Filamentous phage $\mathrm{X}$ (Bradley et al., 1981 a) the X-like phages IKe (Khatoon et al., 1972) and $\mathrm{I}_{2}-2$ (Coetzee et al., 1982; Bradley et al., 1983), phages PR64FS (Coetzee et al., 1980), fd (Marvin \& Hoffmann-Berling, 1963), SF (Coetzee et al., 1986) and tf-1 (Coetzee et al., 1987) were compared serologically with phage X-2 (see Results). The RNA-containing phage C-1 (Sirgel et al., 1981) and filamentous phages X, IKe, PR64FS and fd were used as controls in organic solvent and RNAase susceptibility tests. Phage PR64FS was also used to assess constitutive production of conjugative pili by plasmids of IncI incompatibility complex (see Table 2) while phages IKe and $\mathrm{I}_{2}-2$ were also tested for possible lytic action on bacterial strains harbouring the IncX plasmid R6K.

Media and antibacterial agents. These were according to Coetzee et al. (1979).

General phage techniques and production of phage lysates. The methods of Adams (1950) were used. The incubation temperature was $37^{\circ} \mathrm{C}$, except for phages D (Coetzee et al., 1985a) or pilH $\alpha$ (Coetzee et al., 1985 b) when the temperature was $26^{\circ} \mathrm{C}$. Plates were incubated overnight.

Selection of phage-resistant clones of strain JE257I(R6K). Selective top-layer nutrient agar (5 ml) containing ampicillin $\left(40 \mu \mathrm{g} \mathrm{ml}^{-1}\right)$ and streptomycin sulphate $\left(30 \mu \mathrm{g} \mathrm{ml}^{-1}\right)$ were seeded with about $4 \times 10^{6}$ organisms of the plasmid-carrying strain in the presence of $1 \times 10^{10}$ p.f.u. phage X-2 before pouring over the surface of a nutrient agar plate. After setting, the plate was incubated. Overgrowing colonies on the otherwise relatively clear surface were then picked off and purified by repeated single colony isolation on selective nutrient agar.

Ribonuclease and organic solvent sensitivity of phage suspensions. The former was assessed as described by Bradley et al. $(1981 \mathrm{a})$. The latter tests involved the mixing of solvent and broth lysate of phage $1: 3(\mathrm{v} / \mathrm{v})$ in flat stoppered vessels and shaking in a shaker at two oscillations $\mathrm{s}^{-1}$ at $25^{\circ} \mathrm{C}$ for $1 \mathrm{~h}$ as recommended by Ackermann et al. (1978).

Phage isolation. Sewage samples (obtained from various sewage works in the Pretoria-Johannesburg area) were enriched with broth cultures of JE2571-2(R6K) or M827-2(R6K) according to the method of Bradley et al. (1981 a). Dilutions of the supernatants of the lysates were then spotted on lawns of the above two plasmid-carrying strains growing on nutrient agar and on the same medium containing $25 \mu \mathrm{g} \mathrm{RNAase} \mathrm{m}^{-1}$ (BDH). As an RNA-containing phage was being sought (see Introduction) this approach enabled such prospective phages to be detected immediately by noting the absence of plaques on the RNAase-containing member of a pair of plates (see Coetzee et al., 1985a).

Transfer of plasmids by plate mating. This was done by the method of Bradley et al. (1980).

Phage antiserum. Ten injections of $1 \mathrm{ml}$ of broth suspensions of phages $\mathrm{X}$ and X-2 (see Results) (titres $>1 \times 10^{10}$ p.f.u. $\mathrm{ml}^{-1}$ ) were given intravenously at $2 \mathrm{~d}$ intervals to groups of three rabbits respectively. After resting the animals for $15 \mathrm{~d}$, a booster injection of $5 \mathrm{ml}$ of the corresponding phage suspension was administered subcutaneously; $10 \mathrm{~d}$ later, blood was collected from the animals and the serum warmed at $56^{\circ} \mathrm{C}$ for 30 min to inactivate complement.

Phage growth on bacterial strains harbouring plasmids repressed for pilus synthesis. The methods of Coetzee et al. (1986) were used employing newly formed transconjugants, produced by the temporary derepression methods of Bradley et al. (1980) and Bradley \& Fleming (1983), of the plasmids under study.

Electron microscopy. Techniques for visualizing phage-pilus and bacterium-phage mixtures were as described by Bradley (1980) and Bradley et al. (1981a, 1982a). For immune electron microscopy, grid-labelling with antiserum to phages X, X-2 (see Results) or IKeh (anti-IKeh kindly supplied by R. B. Grant) was done by the method of Lawn (1967).

\section{RESULTS}

\section{Transfer of plasmids}

The IncX plasmid R6K transferred on agar surfaces from $E$. coli strain JE2571-1 to $S$. typhimurium M827-2, Serratia marcescens Sr41-2 or K. pneumoniae G162 and K. oxytoca G147 at frequencies $>8 \times 10^{-3}$ transconjugants per donor $\mathrm{h}^{-1}$. Similar frequencies were recorded for transfer of the plasmid from these transconjugants back to $E$. coli strain JE2571-1. Transfer of 


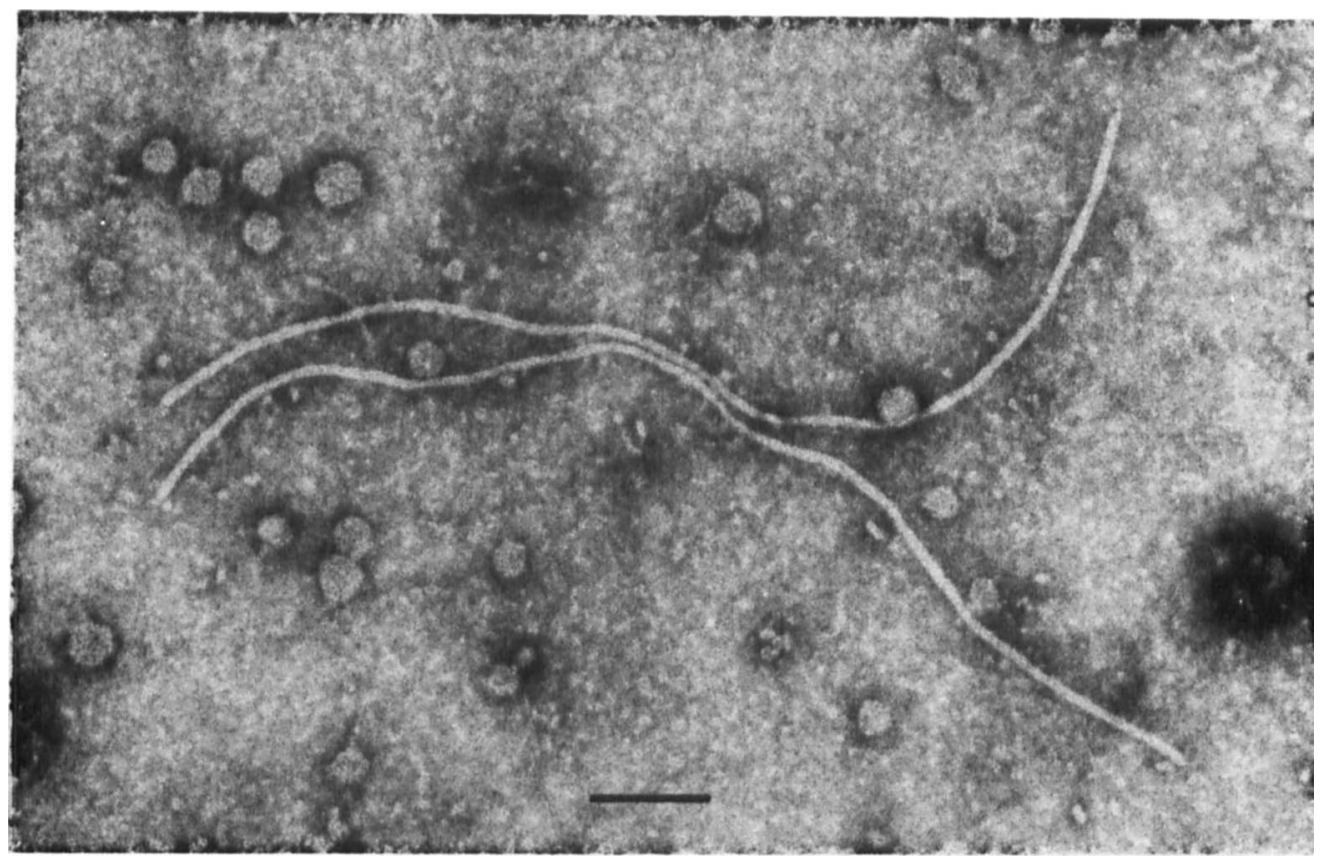

Fig. 1. Phage X-2 virions. Bar, $100 \mathrm{~nm}$.

this plasmid between the $E$. coli or $S$. typhimurium strains and $P$. mirabilis PM5006, $P$. morganii 2815-2, P. rettgeri NCTC 8993 or Pr. alcalifaciens P29-2 occurred at much lower frequericies of about $5 \times 10^{-5}$ transconjugants per donor $\mathrm{h}^{-1}$. Similar low frequencies were recorded for the passage of plasmid R6K from the latter transconjugants back to $E$. coli JE2571-1 or $S$. typhimurium M827-2. The remainder of the IncX plasmids (Table 2) transferred between all the above strains also at frequencies of about $5 \times 10^{-5}$ transconjugants per donor $\mathrm{h}^{-1}$, in keeping with their repressed state of conjugative pilus synthesis (Bradley, 1980; Bradley et al., 1981a).

Each of ten phage-X-2-resistant clones (see below) of JE2571(R6K) in matings with strain JE2571-1 failed to yield transconjugants: i.e. the transfer frequency was $<4 \times 10^{-8}$ transconjugants per donor $\mathrm{h}^{-1}$.

\section{Isolation of a JE2571(R6K)-dependent bacteriophage}

Many hundreds of enriched sewage samples were examined over a period of 7 years but none yielded a prospective RNA-containing phage which only plated on the non-RNAase containing member of a pair of plates. Occasionally, a lysate contained a phage which plated equally well on both the $E$. coli and $S$. typhimurium indicator strains. Some of these exceptional lysates were investigated. They usually yielded tailed somatic-adsorbing phages which infected members of the above two genera, or a phage similar to phage X (J. N. Coetzee, unpublished). One such lysate contained a phage which differed from phage $X$ in many respects (see below). The phage was named phage X-2 and was routinely propagated on M827-2(R6K). Plaque-forming titres of $>1 \times 10^{10} \mathrm{ml}^{-1}$ were regularly obtained.

\section{Properties of phage $X-2$}

Plaque morphology. The phage formed turbid plaques on susceptible organisms. The plaques were very uniform, about $1.1 \mathrm{~mm}$ in diameter, and did not vary on different hosts. The plaques were more turbid and slightly larger than those produced by phage $X$.

Morphology and adsorption site. The phage X-2 virion was filamentous, undulating, and had a thickness of about $10 \mathrm{~nm}$. Measurement of 53 virions gave a mean length of $950 \pm 30 \mathrm{~nm}$ and both ends were slightly pointed with no additional terminal structures evident (Fig. 1). 


\section{Table 1. Immune electron microscopy of $X$-like phages}

For antisera to phages X-2 and X, see Results. Antiserum to phage IKeh, a broad host range mutant of phage IKe (Grant et al., 1978), was kindly supplied by R. B. Grant. Grid-labelling of phages with antisera was done according to Lawn (1967).

\begin{tabular}{lccc} 
& \multicolumn{3}{c}{ Labelling with antiserum to phage: } \\
Phage & $\overbrace{\mathrm{X}}^{\mathrm{X}-2}$ & IKe $h$ \\
$\mathrm{X}$ & + & - & - \\
$\mathrm{X}-2$ & - & + & - \\
$\mathrm{IKe}$ & - & - & + \\
$\mathrm{I}_{2}-2$ & $-*$ & $\mathrm{ND}$ & + \\
ND, Not done. \\
+, Immunoglobulin labelling;,- no labelling. \\
*, Results from Bradley et al. (1983).
\end{tabular}

All attempts to demonstrate adsorption of phage X-2 to X pili or R775 pili (see below) in the electron microscope failed. This applies to studies of many pili which were attached to producer cells and large numbers of loose-lying pili. Even after $5 \mathrm{~h}$ incubation, mixtures of virions and $\mathrm{X}$ or R775 conjugative pili showed the objects separated and not forming complexes. A possible relationship between plasmid $R 6 \mathrm{~K}$ conjugative pilus formation and phage X-2 susceptibility of the plasmid-harbouring strain JE2571 was established by examining two phage-resistant colonies of JE2571(R6K) investigated for conjugal transfer of the plasmid (see above). Bacteria from the colonies were grown under optimum conditions for pilus production ( $3 \mathrm{~h}$ on Brain Heart nutrient agar) and then examined for the presence of pili by electron microscopy. No pili were detected in preparations of either of the two colonies (not shown).

Phage serology. One of the rabbits yielded a phage $\mathrm{X}$ anti-serum with a $K$ value of $110 \mathrm{~min}^{-1}$ and an anti-phage X-2 serum with a $K$ value of $225 \mathrm{~min}^{-1}$ was obtained from another rabbit. Neither of the antisera had any neutralizing effect on the heterologous phage. The two phages thus had antigenically different adsorption sites. Neither of the antisera had a neutralizing effect on the other filamentous phages tested, namely the X-like phages IKe and $I_{2}-2$ and phages PR64FS, fd, SF and tf-1.

Immune electron microscopy (not illustrated; results listed in Table 1) proved that the remaining surfaces of phages $X-2, X$ and IKe were different. By inference, phage $I_{2}-2$ which is serologically closely related to phage IKe (Bradley et al., 1983) also differed from phages X-2 and $X$.

Sensitivity to RNAase and organic solvents. The plating titre of filamentous phages $\mathrm{X}-2, \mathrm{X}, \mathrm{IKe}$ and $f d$ on their respective hosts was unaffected by the presence of $25 \mu \mathrm{g}$ RNAase $\mathrm{ml}^{-1}$ in media while that of the positive control, phage $\mathrm{C}-1$, was reduced to zero.

Treatment with chloroform reduced the titres of phages X-2, X, IKe and fd to zero. Phage C-1 was unaffected. Phages $\mathrm{X}-2, \mathrm{IKe}, \mathrm{fd}$ and $\mathrm{C}-1$ were refractory to diethyl ether but this solvent reduced the titre of phage $X$ by about $95 \%$

These results are compatible with the filamentous morphology of phage X-2 and the reactions of the control phages, with the exception of phage X, were as expected (see Amako \& Yasunaka, 1977). Results of the latter phage, with regard to diethyl ether treatment, are at variance with those previously reported (Bradley et al., 1981 a) and could be explained by the fact that, as was the case with chloroform (Coetzee et al., 1979), exposure of phage $\mathrm{X}$ to diethyl ether was also only for $10 \mathrm{~min}$.

Host ranges of phages. Phage X-2 only plated on E. coli, Sr. marcescens or S. typhimurium strains carrying the IncX plasmid R6K or the unique plasmid R775 (Table 2). In keeping with the repressed state of plasmid R6K pilus synthesis in strains of Proteus, Morganella, Rettgerella 
Table 2. Host range of phages $X-2$ and $X$

Dilutions of phage suspensions (about $2 \times 10^{10}$ p.f.u. $\mathrm{ml}^{-1}$ ) were dropped on lawns of organisms contained in top-layer agar. Plates were incubated overnight at $37^{\circ} \mathrm{C}$. Phage propagation and temporary derepression spot tests were done as referred to in Methods. Phage action: + , plaque formation; - , no visible action; $(+)$, positive phage propagation and temporary derepression spot tests obtained in at least two experiments; $(-)$, negative phage propagation and temporary derepression spot tests obtained in three experiments.

\begin{tabular}{|c|c|c|c|c|}
\hline \multirow[b]{2}{*}{ Host } & \multirow{2}{*}{$\begin{array}{l}\text { Plasmid } \\
\text { Inc group }\end{array}$} & \multicolumn{2}{|c|}{ Phage action } & \multirow[b]{2}{*}{ Reference } \\
\hline & & $X-2$ & $\mathrm{X}$ & \\
\hline JE2571(R6K) & $\mathbf{X}$ & + & + & Bradley (1980) \\
\hline M827-2(R6K) & $\mathbf{X}$ & + & + & \\
\hline SR41-2(R6K) & $\mathbf{X}$ & + & + & \\
\hline G162(R6K) & $\mathbf{X}$ & $-(-)$ & + & \\
\hline G147(R6K) & $\mathbf{X}$ & $-(-)$ & + & \\
\hline PM5006(R6K) & $\mathbf{X}$ & $-(+)$ & $-(+)$ & This investigation \\
\hline 2815-2(R6K) & $\mathbf{X}$ & $-(+)$ & $-(+)$ & · \\
\hline NCTC8893(R6K) & $\mathbf{X}$ & $-(+)$ & $-(+)$ & \\
\hline P29-2(R6K) & $\mathbf{X}$ & $-(+)$ & $-(+)$ & \\
\hline JE2571-1(R485) & $X$ & $-(+)$ & $-(+)$ & Bradley (1978) \\
\hline M827-2(pHH1187) & $\mathbf{X}$ & $-(+)$ & $-(+)$ & \\
\hline JE2571-2(TP231) & $\mathbf{X}$ & $-(+)$ & $-(+)$ & Bradley (1980) \\
\hline M827-2(TP227) & $\mathbf{X}$ & $-(+)$ & $-(+)$ & Dianicy $(1700)$ \\
\hline M827-2(TP228) & $\mathbf{X}$ & $-(+)$ & $-(+)$ & \\
\hline JE2571(PVS112) & $\mathbf{X}$ & $-(+)$ & $-(+)$ & \\
\hline JE2571-2(PVS115) & $\mathbf{X}$ & $-(+)$ & $-(+)$ & Caudrey \& stanisicn $(19 / 9)$ \\
\hline JE2571(R386) & F1 & $-(-)$ & $-(-)$ & Dennison (1972) \\
\hline JE2571(R64drd11) & $I_{1}$ & $-(-)$ & $-(-)$ & Datta et al. (1971) \\
\hline M827-2(TP114drpl) & $I_{2}$ & $-(-)$ & + & Bradley et al. (1983) \\
\hline M827-2(Rip69) & $\mathbf{M}$ & $-(-)$ & + & Coetzee (1979); Coetzee et al. (1983) \\
\hline JE2571(R15) & $\mathbf{N}$ & $-(-)$ & + & Jacob et al. $(1977)$ \\
\hline JE2571-2(RP4) & $\mathbf{P}$ & $-(-)$ & + & Coetzee et al. (1979) \\
\hline M827-2(RA3) & $\mathbf{U}$ & $-(-)$ & + & Tschäpe et al. (1981) \\
\hline JE2571(R1460) & $\mathrm{U}$ & $-(-)$ & + & Bradley et al. $(1982 b)$ \\
\hline JE2571-2(RSa) & W & $-(-)$ & $-(+)$ & Coetzee et al. (1979) \\
\hline JE2571-1(R775) & Unique & + & + & \\
\hline M827-2(R775) & Unique & + & + & Bradley et al. $(1981 a)$ \\
\hline SR41-2(R775) & Unique & + & + & \\
\hline
\end{tabular}

and Providencia (see above), phage X-2 only propagated on them as efficiently as on E. coli or $S$. typhimurium strains carrying other repressed IncX plasmids. Phage X-2 did not even propagate on strains of $K$. pneumoniae or $K$. oxytoca carrying R6K, although the plasmid formed pili constitutively in these strains (Table 2). Neither did it propagate on strains of $E$. coli or $S$. typhimurium harbouring plasmids belonging to Inc groups $\mathrm{I}_{2}, \mathrm{M}, \mathrm{N}, \mathrm{P}, \mathrm{U}$ or $\mathrm{W}$ on which phage $\mathrm{X}$ plated or propagated. The reactions of phage X (Table 2) were as reported (Bradley et al., $1981 \mathrm{a}$, 1983). Both these phages failed to plate or propagate on strains harbouring IncI $I_{1}$ or IncF1 plasmids (Table 2) or on E. coli and $S$. typhimurium strains carrying plasmids of the other Inc groups mentioned in Methods encoding thick flexible pili constitutively (not shown).

Phages $\mathrm{IKe}$ and $\mathrm{I}_{2}-2$ had no visible action on strains of $E$. coli, $S$. typhimurium or $S r$. marcescens carrying the IncX plasmid R6K (not shown).

\section{DISCUSSION}

Phage $\mathrm{X}-2$ is serologically unrelated to phage $\mathrm{X}$ and the $\mathrm{X}$-like phages $\mathrm{IKe}$ and $\mathrm{I}_{2}-2$ (Table 1 ). Phage X-2 lacks the curly appearance of phage X (Bradley et al., 1981 a) and the phages differ in their reactions to diethyl ether. The host-range of phage X-2 also differs from those of phages IKe and $\mathrm{I}_{2}-2$ (Table 2 and Bradley et al., 1983), particularly in that the latter have no visible effect on JE2571(R6K), the host strain of the former phage. 
While phages $\mathrm{X}$ and IKe adsorb to the tips of pili determined by plasmids of various Inc groups (Bradley, 1979; Bradley et al., 1981 a, 1983) the adsorption site of phage X-2 as well as that of phage $\mathrm{I}_{2}-2$ (Coetzee et al., 1982) has not been determined. For the latter phage it was concluded that either adsorption to $\mathrm{IncI}_{2}$-plasmid-coded pili was very inefficient or that the preparative methods broke apart the phage-pilus complexes. For phage X-2 attention was also given to pili still attached to bacterial cells in case phage only adsorbed to such pili, but this approach also proved futile. However, indirect evidence implicating $X$ pili in the adsorption process was obtained. Firstly, ten phage-X-2-resistant clones of strain JE2571(R6K), which still displayed the antibiotic-resistance markers of the plasmid, were sterile in matings with JE25711. Sex pili are implicated in the conjugative process (Ottow, 1975) and one explanation for this behaviour would be that these phage-resistant clones lacked sex pili. This reasoning was supported by the fact that no pili could be seen on the two of these phage-resistant clones examined. Thus loss of sensitivity to phage X-2 coincided with loss of X pili and adsorption of the phage to somatic sites coded by the plasmid may possibly also be excluded.

If adsorption of phage X-2 does occur to pili, the adsorption site must be different from that of phage $X$ (see above) but could also be on the tips of these pili as tips of F pili can accommodate at least three f1 phages simultaneously (Caro \& Schnös, 1966) and the tips of IncN pili adsorb phage IKe and also the lipid-containing phage PR4 (Bradley, 1979). Alternatively the adsorption site of phage X-2 could be on the pilus shafts. This would be in keeping with the restricted host range of phage X-2 in comparison with that of phage $\mathrm{X}$ (Table 2; see Coetzee $e t$ $a l ., 1979$ ) and in that way resemble phage $\mathrm{C} 2$ (Bradley et al., 1982a) or phage tf-1 (Coetzee et al., 1987).

The host range of phage X-2 is limited to IncX plasmid- and the unique plasmid R775harbouring strains of bacteria. Differences in the host range of phages X-2 and X with regard to the IncX plasmid R6K in the K.pneumoniae strain G162 and strain G147 of K. oxytoca (Table 2) could mean that the Klebsiella strains, while allowing adsorption, cannot support the intracellular growth of phage X-2 (see Bradley et al., 1981a,b). Keeping the latter limitation in mind, the restricted host range of phage $X-2$ could make it more useful than phage $X$ in identifying IncX and R775 plasmids.

We thank Jeanette Whelan and Bertha Hounsell for excellent technical assistance. D.E. B. is in receipt of a grant (no. MT5608) from the Medical Research Council of Canada.

\section{REFERENCES}

Ackermann, H.-W., Audurier, A., Berthiaume, L., Jones, L. A., Mayo, J. A. \& Vidaver, A. K. (1978). Guidelines for bacteriophage characterization. $A d$ vances in Virus Research 23, 1-24.

ADAMS, M. H. (1950). Methods of study of bacterial viruses. Methods in Medical Research 2, 1-73.

AmaKo, K. \& YasunaKa, K. (1977). Ether induced morphological alteration of Pf-1 filamentous phage. Nature, London 267, 862-863.

BRADLEY, D. E. (1978). Determination of very thin pili by the bacterial drug resistance plasmid R485. Plasmid 1, 376-387.

BRADLEY, D. E. (1979). Morphology of pili determined by the $\mathrm{N}$ incompatibility group plasmid $\mathrm{N} 3$, and interaction with bacteriophages PR4 and IKe. Plasmid 2, 632-636.

BRADLEY, D. E. (1980). Morphological and serological relationships of conjugative pili. Plasmid 4, 155-169.

BRADLEY, D. E. (1983). Derepressed plasmids of incompatibility group $I_{1}$ determine two different morphological forms of pilus. Plasmid 9, 331-334.

BRADLEY, D. E. (1985). Transfer systems of K88 and K99 plasmids. Plasmid 13, 118-128.

Bradley, D. E. \& Fleming, J. (1983). Incompatibility group identification for repressed plasmids using host cell lysis by specific bacteriophages. Journal of Microbiological Methods 1, 171-176.

Bradley, D. E., Taylor, D. E. \& Cohen, D. R. (1980). Specification of surface mating systems among conjugative drug resistance plasmids in Escherichia coli K-12. Journal of Bacteriology 143, 1466-1470.

Bradley, D. E., Coetzee, J. N., Bothma, T. \& Hedges, R. W. (1981a). Phage X: a plasmiddependent, broad host range, filamentous bacterial virus. Journal of General Microbiology 126, 389-396.

Bradley, D. E., Coetzee, J. N., Bothma, T. \& Hedges, R. W. $(1981 b)$. Phage t: a group T plasmiddependent bacteriophage. Journal of General Microbiology 126, 397-403.

Bradley, D. E., Sirgel, F. A., Coetzee, J. N., Hedges, R. W. \& Coetzee, W. F. (1982a). Phages $\mathrm{C}-2$ and $\mathrm{J}$ : IncC and IncJ plasmid-dependent phages, respectively. Journal of General Microbiology 128, 2485-2498. 
Bradley, D. E., Aoki, T., Kitao, T., Arai, T. \& TSCHÄPE, H. $(1982 b)$. Specification of characteristics for the classification of plasmids in incompatibility group U. Plasmid 8, 89-93.

Bradley, D. E., Coetzee, J. N. \& Hedges, R. W. (1983). IncI ${ }_{2}$ plasmids specify sensitivity to filamentous bacteriophage IKe. Journal of Bacteriology 154, 505-507.

CARO, L. G. \& SCHNÖs, M. (1966). The attachment of the male-specific bacteriophage $F 1$ to sensitive strains of Escherichia coli. Proceedings of the National Academy of Sciences of the United States of America 56, 126-132.

CAUDRY, S. D. \& Stanisich, V. A. (1979). Incidence of antibiotic-resistant Escherichia coli associated with frozen chicken carcasses and characterization of conjugative $\mathbf{R}$ plasmids derived from such strains. Antimicrobial Agents and Chemotherapy 16, 701-709.

Coetzee, J. N. (1979). Patterns of mobilization of the Proteus mirabilis chromosome by $\mathbf{R}$ plasmids. Journal of General Microbiology 111, 243-251.

Coetzee, J. N. (1983). Lysogeny in Proteus rettgeri and the host-range of $P$. rettgeri and $P$. hauseri bacteriophages. Journal of General Microbiology 131, 219229.

Coetzee, J. N., Lecatsas, G., Coetzee, W. F. \& HedGes, R. W. (1979) Properties of R plasmid R772 and the corresponding pilus-specific phage PR772. Journal of General Microbiology 110, 263-273.

Coetzee, J. N., Sirgel, F. A. \& Lecatsas, G. (1980). Properties of a filamentous phage which adsorbs to pili coded by plasmids of the IncI complex. Journal of General Microbiology 117, 547-551.

Coetzee, J. N., Bradley, D. E. \& Hedges, R. W. (1982). Phages $\mathrm{I} \alpha$ and $\mathrm{I}_{2}-2$ : IncI plasmid-dependent bacteriophages. Journal of General Microbiology 128 , 2797-2804

Coetzee, J. N., Bradley, D. E., Hedges, R. W., Fleming, J. \& LeCaTsas, G. (1983). Bacteriophage $\mathbf{M}$ : an incompatibility group $\mathbf{M}$ plasmid-specific phage. Journal of General Microbiology 129, 22712276.

Coetzee, J. N., Bradley, D. E., Lecatsas, G., DU ToIT, L. \& HedGes, R. W. (1985a). Bacteriophage $D$ : an IncD group plasmid-specific phage. Journal of General Microbiology 131, 3375-3383.

Coetzee, J. N., BRADLEy, D. E., Fleming, J., DU Toit, L., Hughes, V. M. \& Hedges, R. W. (1985 b). Phage pilH $\alpha$ : a phage which adsorbs to IncHI and IncHII plasmid-coded pili. Journal of General Microbiology 131, 1115-1121.

Coetzee, J. N., Bradley, D. E., Hedges, R. W., Hughes, V. M., MCCONNEll, M., DU TOIT, L. \& TweEhUIZEN, M. (1986). Bacteriophages $\mathrm{F}_{0} l a c h$, SR, SF: phages which adsorb to pili encoded by plasmids of the new S-complex. Journal of General Microbiology 132, 2907-2917.

Coetzee, J. N., Bradley, D. E., Hedges, R. W., Tweehuizen, M. \& DU ToIT, L. (1987). Phage tf-1: a filamentous bacteriophage specific for bacteria harbouring the IncT plasmid pIN25. Journal of General Microbiology 133, 953-960.

DatTA, N. (1979). Plasmid classification: incompatibility grouping. In Plasmids of Medical, Environmental and Commercial Importance, pp. 3-12. Edited by K. N. Timmis \& A. Puhler. Amsterdam: Elsevier/ North-Holland Biomedical Press.

Datta, N., Hedges, R. W., Shaw, E. J., Sykes, R. P. \& RichMOND, M. H. (1971). Properties of an R factor from Pseudomonas aeruginosa. Journal of Bacteriology 108, 1244-1249.

DENNISON, S. (1972). Naturally occurring $R$ factor, derepressed for pilus synthesis, belonging to the same compatibility group as the sex factor F of $E$. coli K12. Journal of Bacteriology 109, 416-419.

Grant, R. B., Whiteley, M. H. \& Shapley, A. J. (1978). Plasmids of incompatibility group $P$ code for the capacity to propagate bacteriophage IKe. Journal of Bacteriology 136, 808-811.

Hedges, R. W., Datta, N., Coetzee, J. N. \& DENNISON, S. (1973). R factors from Proteus morganii. Journal of General Microbiology 77, 249-259.

JaCob, A. E., Shapiro, J. A., Yamamoto, L., SMITH, D. I., Cohen, S. N. \& Berg, D. (1977). Plasmids studied in Escherichia coli and other enteric bacteria. In DNA Insertion Elements, Plasmids and Episomes, pp. 607-638. Edited by A. I. Bukhari, J. A. Shapiro \& S. L. Adhya. Cold Spring Harbor, NY: Cold Spring Harbor Laboratory.

KHATOON, H., IYER, R. V. \& IYER, V. N. (1972). A new filamentous bacteriophage with sex-factor specificity. Virology 48, 145-155.

Kontamichalou, P., Mitani, M. \& Clowes, R. C. (1970). Circular R-factor molecules controlling penicillinase synthesis, replicating in Escherichia coli under either relaxed or stringent control. Journal of Bacteriology 104, 34-44.

LAWN, A. M. (1967). Simple immunological labelling method for electron microscopy and its application to the study of filamentous appendages of bacteria. Nature, London 214, 1151-1152.

Marvin, D. A. \& Hoffmann-Berling, H. (1963). Physical and chemical properties of two new small bacteriophages. Nature, London 197, 517-518.

Matsumoto, H., Tazaki, T. \& Hosogaya, S. (1973). A generalized transducing phage of Serratia marcescens. Japanese Journal of Microbiology 17, 473-479.

Otтow, J. C. G. (1975). Ecology, physiology, and genetics of fimbriae and pili. Annual Review of Microbiology 29, 79-108.

Sirgel, F. A., Coetzee, J. N., Hedges, R. W. \& LeCATSAS, G. (1981). Phage C-1: an IncC group plasmid-specific phage. Journal of General Microbiology 122, 155-160.

SPRatt, B. G., Rowbury, R. H. \& Meynell, G. G. (1973). The plasmid of Salmonella typhimurium LT2. Molecular and General Genetics 121, 347-353.

TSCHÄPE, H., TIETZE, E. \& KoCH, C. (1981). Characterization of conjugative $\mathbf{R}$ plasmids belonging to the new incompatibility group IncU. Journal of General Microbiology 127, 155-160. 